\title{
Monetary Policy in the Conservatives' 2015 General Election Campaign
}

La politique monétaire dans la campagne législative des Conservateurs en 2015

\section{Nathalie Champroux}

\section{(2) OpenEdition}

\section{Journals}

Electronic version

URL: http://journals.openedition.org/rfcb/551

DOI: $10.4000 / \mathrm{rfcb} .551$

ISSN: 2429-4373

\section{Publisher}

CRECIB - Centre de recherche et d'études en civilisation britannique

\section{Electronic reference}

Nathalie Champroux, " Monetary Policy in the Conservatives' 2015 General Election Campaign », Revue Française de Civilisation Britannique [Online], XX-3 | 2015, Online since 01 December 2015, connection on 19 April 2019. URL : http://journals.openedition.org/rfcb/551 ; DOI : 10.4000/rfcb.551

This text was automatically generated on 19 April 2019

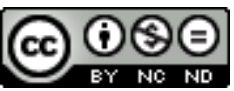

Revue française de civilisation britannique est mis à disposition selon les termes de la licence Creative Commons Attribution - Pas d'Utilisation Commerciale - Pas de Modification 4.0 International. 


\title{
Monetary Policy in the Conservatives' 2015 General Election Campaign
}

\author{
La politique monétaire dans la campagne législative des Conservateurs en 2015
}

\author{
Nathalie Champroux
}

1 For the outgoing Coalition government and Conservative leader and Prime Minister David Cameron, the 2015 general election date could hardly have come at a better time from the point of view of the economy. At first glance, the statistics tended to show the government had effectively presided over a firm and balanced recovery, leading the country to enviable steady growth, zero inflation, falling unemployment and a lower budget deficit. There was therefore hardly any doubt that the Conservatives' campaign would focus on this great asset. Indeed, even before the dissolution of Parliament, David Cameron started communicating a positive message about his government's proven economic competence, ${ }^{1}$ while Chancellor of the Exchequer George Osborne contrasted this competence to the economic "chaos" 2 a Labour team would bring.

2 This article examines how the Conservatives exploited the United Kingdom's good economic performance in their 2015 general election campaign and, in particular, seeks to identify the role attributed to the last five years' monetary policy. Of course, monetary policy on its own cannot exclusively account for Britain's relative prosperity. Nevertheless, if Osborne's 2013 Budget speech to the House of Commons ${ }^{3}$ is to be believed, monetary policy should be given some credit. This article is therefore interested in how the Conservatives treated this particular issue: whether they acknowledged the effectiveness of the independent Monetary Policy Committee of the Bank of England or whether they claimed full merit for all the factors supporting Britain's economic success, thus adding to the monetary policy re-politicization process observed in 2013. It will focus on the Conservatives' public electoral campaign, as relayed by the media to ordinary citizens, and not on the specially tailored messages delivered to specific economic or political assemblies. 
The article starts with the contextualisation of the analysis. Section 1 explains how the introduction of forward guidance in Britain in 2013 entailed a process of monetary policy re-politicization. Section 2 presents an overview of the United Kingdom's economic conditions at the time of the 2015 general election, which will help readers to understand the various arguments the Conservatives put forward in their campaign. The article then analyses the campaign itself. Section 3 explains the process which underpinned the Conservatives' decision to focus their campaign on economic aspects. Section 4 describes the economic message that was conveyed and Section 5 seeks to identify more particularly how the Conservatives dealt with monetary policy. The article finishes with an attempt at explaining why the Conservatives chose to deal with their own monetary policy actions in the way they did during the campaign.

\section{The 2013 Process of Monetary Policy Re-Politicization}

Most elements of Britain's current monetary policy were introduced by previous Conservative and New Labour governments. Conservative Chancellors of the Exchequer Norman Lamont and Kenneth Clarke set up the bases of direct inflation targeting, ${ }^{4}$ just after sterling left the Exchange Rate Mechanism of the European Monetary System in September 1992. New Labour Chancellor Gordon Brown then reinforced the policy with the Bank of England Act voted in Parliament in 1998. A more formal framework was established, with the Treasury being henceforth only responsible for defining price stability, while operational independence was granted to the Bank of England. More explicitly, the Treasury fixed the inflation target ${ }^{5}$ and the Bank's Monetary Policy Committee (MPC) decided on the proper use of monetary policy instruments to achieve the target in the medium term. Then, with the financial crisis that started in the summer of 2007, Brown's successor, Alistair Darling, agreed to gradual reductions of the Bank of England's base rate to close to zero percent, from December 2007 to March 2009. Finally, Darling authorized the first waves of quantitative easing, with asset purchases totalling £200 billion from March 2009 to January 2010.

Cameron's team subsequently made their own particular contributions to Britain's monetary policy framework. Osborne allowed for further quantitative easing in October 2011, and February and July 2012, which increased the amount of government debt purchases from $£ 200$ billion to $£ 375$ billion. In July 2012, the Treasury and the Bank of England introduced the Funding for Lending Scheme (FLS), which permitted commercial banks and building societies to borrow more cheaply from the central bank. In turn, households (until January 2014 only) and, especially, companies, had easier access to loans. In addition to these measures, the Conservative Chancellor was at the origin of the inclusion of forward guidance in the Bank of England's monetary strategy. ${ }^{6}$ Osborne appointed Mark Carney as the Governor of the Bank of England. He had headhunted Carney from the Bank of Canada, where Carney had famously pioneered the use of the unconventional instrument. Osborne also officially assumed the responsibility of opening the door to the adoption of forward guidance, in the remit ${ }^{7}$ he sent to the Governor of the Bank of England at the time of the 2013 Budget. In his Budget speech, he even presented this adoption as the "monetary reform" ${ }^{8}$ which constituted one of the three pillars of the reinforcement of the government's economic plan. In reality, the adoption of forward guidance fell short of the commentators' expectations of a complete change in the British 
monetary policy framework. Yet Osborne's move and speech should be remembered as they re-politicized monetary policy in the United Kingdom.

6 To understand the re-politicization of monetary policy, it is necessary to go back to the opposite concept of de-politicization. According to political scientist Matthew Flinders, de-politicization happens when "politicians [...] attempt to move to an indirect governing relationship and/or seek to persuade the demos that they can no longer be reasonably held responsible for a certain issue, policy field or specific decision." As far as British monetary policy is concerned, this phenomenon occurred with the introduction of the minimum lending rate in $1972^{10}$ and the participation of sterling in the ERM at the beginning of the 1990s. Then, since 1998, when Gordon Brown entrusted the MPC with formulating monetary policy, British governments have relinquished their power over the manipulation of monetary policy instruments - the main instrument being the Bank base rate, until the zero lower bound was reached in 2009.

But Osborne's 2013 Budget measure and speech reversed the trend. First, the Chancellor encompassed the government in the "we" he used to refer to the actors responsible for " [keeping] interest rates at record lows", ${ }^{11}$ whereas only the Bank of England could take credit for the interest rate stability. Second, his so-called "reform" was more a slight interference with the Bank of England's operational independence. Indeed, Osborne did not act on the government's prerogatives: he neither gave a new definition of price stability nor changed the target, which he could have replaced by a new target altogether (like nominal output) or by a new inflation target rate at $3 \%$ or $4 \%$ of CPI, for example. Instead, the Chancellor incited the MPC to adopt a new instrument. He made "clear that the Committee may wish to issue explicit forward guidance, including using intermediate thresholds" 12 and presented the United States Federal Reserve's experiment with the unemployment threshold as an example to follow. Even if he cautiously declared that " whether intermediate thresholds [were] used [would] be an operational matter for the independent $M P C,{ }^{13}$ it was absolutely clear that he advocated - and expected - such a use. The chicken-and-egg question will remain unanswered here. Was Osborne the initial instigator of the adoption of forward guidance or, to mix metaphors, was he simply holding the magician's hat for Carney's rabbit? Whatever the causal direction, the essential point is the impression conveyed: that of the Treasury getting its hands back on monetary policy.

\section{The Economic Context of the 2015 General Election}

In 2013, the Chancellor's directions were understood as a clear recourse to monetary policy to rescue the economy in the context of asphyxiating fiscal austerity. To be fair, Osborne did not convey this precise message. Rather he presented "credible" fiscal policy as a help which "creat [ed] the space for", or "securely anchored", ${ }^{14}$ active monetary policy. But he gave monetary policy "a full role in supporting the economy", ${ }^{15}$ while this role was not linked in any way to efforts to reduce budget deficits, even in the long term. There was an echo of the Medium Term Financial Strategy of the early 1980s, so much so that the supply side reforms of the government's plan were not much remarked upon by commentators.

As it turned out, by 2015, the statistics tended to confirm the effectiveness of the government's plan and its reinforcement performed in 2013, as regards both budget 
deficit reduction and economic growth. Questions of fiscal policy are dealt with in another article of this special issue ${ }^{16}$ and so are left aside here. Let it simply be noted that, according to the Office for National Statistics (ONS), the deficit, as measured by the public sector net borrowing, excluding public sector banks, was cut from $£ 153.5$ billion in 2009-2010 to $£ 87.3$ billion in 2014-2015. In terms of a percentage of GDP, the deficit was reduced, from $10.2 \%$ in $2009-2010$ to $4.8 \%$ in 2014-2015. The latter figure, released on 23 April 2015, ${ }^{17}$ helped the outgoing government claim that their tough fiscal discipline had halved the deficit. Their message, however, ignored the role of the low interest rates paid on government debt, the slow rise in tax receipts recorded since the end of 2012, and the fact that GDP itself had grown.

10 On a quarter-to-quarter basis, after four quarters of encouraging recovery, GDP growth remained stuck in stagnation, or even in decline, from the election of 2010 until the first quarter of 2013. It indeed showed a steady rate after Osborne's announcement of monetary activism intensification. In the end, after five years of Coalition government, GDP growth had fallen, from an annual rate of $1.3 \%$ in 2010 down to $0.7 \%$ in 2011 and $0.2 \%$ in 2012, before recovering to $1.7 \%$ in 2013 and $2.8 \%$ in 2014. The latter GDP growth figure, happily revised up by 0.2 percentage point from previous estimates, was revealed towards the end of the general election campaign, on 31 March 2015. Unsurprisingly, Osborne rejoiced and boasted about the effectiveness of his economic plan, posting the following Tweet straight away: "Hat trick of good news just out from ONS: GDP revised up, consumer confidence up, living standards up. \#LongTermEconomicPlan working." ${ }^{18}$ Indeed, that same day, the media relayed the ONS figures that GDP per head and household consumption had increased by $4.8 \%$ and $3 \%$ respectively since 2010 . Moreover, household consumption did not seem fuelled by credit, as the ratio of household debt to GDP fell by one percentage point, to 93 per cent, in the last quarter of 2014. Yet, critics argued that GDP growth was depending too much on consumer spending, while the latter was depending too much on exceptionally low inflation which needed to rise back to the official $2 \%$ target.

11 As it was, inflation had dramatically decreased. After a peak at $4.48 \%$ in 2011 , up from $3.29 \%$ in 2010, inflation had gradually diminished to $2.83 \%$ in $2012,2.56 \%$ in 2013 and $1.46 \%$ in 2014 . Monthly inflation on a yearly basis in fact had slumped below $1 \%$ in November 2014, to reach $0 \%$ in February 2015, before becoming negative in March 2015, at $-0.08 \%$. Even though inflation thus strongly departed from the Treasury's $2 \%$ target, the news of zero inflation was not unwelcome for the government. This was because the decline was accounted for by temporary decreasing oil prices, while the probability of damaging structural deflation was rejected. For example, when the ONS published an inflation figure at $\mathbf{0 . 5 \%}$ for December 2014, Cameron declared it was "fundamentally good news"19 and Osborne proposed to "celebrate [the] effects of low inflation, not fear them". ${ }^{20}$ Indeed, low inflation meant real family incomes increased. It was all the more true since, as long as inflation predictions were not alarming, the Bank of England's base rate would be kept at its $0.5 \%$ low. And this low had eventually influenced the average interest rates that households were offered by commercial banks, which decreased from $2.98 \%$ to $2.51 \%$ between September 2012 and September 2014. ${ }^{21}$

12 Unemployment had decreased too, following the same general trend as that of inflation: a peak at $8.1 \%$ of the active population in 2011, up from $7.8 \%$ in 2010 , then gradual reductions to $7.9 \%$ in $2012,7.6 \%$ in 2013 and $6.1 \%$ in $2014 . .^{22}$ On a quarterly basis, the unemployment rate had fallen below $7 \%$ in February 2014, and below $6 \%$ in November 2014. It actually went down further to $5.5 \%$ in March and April 2015, ${ }^{23}$ but these figures 
were not officially known at the time of the campaign as they were released on 13 May 2015.

13 There were still dark areas in all the fields described above, though. In money terms, the deficit had only been reduced by $1.75 \%$. Moreover, since the 2010 general election, public borrowing had amounted to more than $£ 550$ billion, that is to say $£ 100$ billion more than the amount New Labour had borrowed in 13 years. There was also the issue of the current account (the difference between the income paid to, and received from, the rest of the world), which showed a $£ 97.9$ billion deficit in 2014. At 5.5\% of national income, this deficit was the highest recorded in history. Further historical comparisons show that GDP per head was $1.2 \%$ below its 2008 peak. Moreover, its average growth failed to reach all social classes throughout the country. Among employed people, five million workers were in low-paid jobs and 700,000 had accepted zero-hour contracts that did not provide them with sufficient income. Wages had been slow to increase too, until March 2014. All employee weekly earning growth had remained below $2.25 \%$ annually since 2009, reaching striking lows of $0.4 \%$ in 2011 and $0.1 \%$ in 2014, even if persons in continuous employment had pay rises of $3.5-4 \%{ }^{24}$ Until inflation disappeared altogether, real wage growth was negative, around $-2.5 \%$, from the first quarter of $2010 .{ }^{25}$ Only since March 2014 could the British rejoice about a timid real pay rise. ${ }^{26}$ Furthermore, zero inflation, when experienced, did not mean all prices remained stable. The annual inflation rate for house prices increased from $7.3 \%$ in 2010 to $10 \%$ in $2014 .{ }^{27}$ Even food prices increased: the 20 most popular branded grocery prices apparently rising by $12 \%$ between 2010 and 2015 . ${ }^{28}$ As proof of spreading poverty under the Coalition government, the number of food banks had soared by $537 \%$, to 421 outlets, while the number of people using them increased by $163 \%$, to 900,000 .

There could of course be a lot more to say about the details of the United Kingdom's 2015 economic situation. But what must be remembered is that, on the whole and despite resilient inequality and poverty, the country appeared to be in a far better economic situation in the spring of 2015 than it had been at the election of 2010. Unsurprisingly, the Conservatives made the most of this in their general election campaign.

\section{The Choice of the Economy as the Main Theme for the Conservatives' Campaign}

The broad topic of "the economy" dominated the national 2015 general election campaign. A study made by Loughborough University reveals the economy remained the second of all issues, and the first substantive matter covered by the press and television in the run up to the elections, as shown in Table 1 below.

Table 1 - Top $10 \mathrm{TV}$ and press election news coverage issues ${ }^{(1)}$

\begin{tabular}{|l|l|l|l|l|l|}
\hline Issues & $\begin{array}{l}30 \text { March- 7 } \\
\text { May }\end{array}$ & $\begin{array}{l}30 \text { March- 8 } \\
\text { April }\end{array}$ & $\begin{array}{l}9 \text { April- 15 } \\
\text { April }\end{array}$ & $\begin{array}{l}16 \text { April- 22 } \\
\text { April }\end{array}$ & $\begin{array}{l}\text { 23 April- 29 } \\
\text { April }\end{array}$ \\
\hline Election process & 1 & 1 & 1 & 1 & 1 \\
\hline Economy & 2 & 2 & 2 & 2 & 2 \\
\hline
\end{tabular}




\begin{tabular}{|l|l|l|l|l|l|}
\hline Taxation & 3 & 3 & 3 & 8 & 4 \\
\hline Constitutional issues & 4 & 9 & 12 & 3 & 3 \\
\hline Employment & 5 & 4 & 11 & 9 & 9 \\
\hline NHS & 6 & 7 & 6 & 5 & 13 \\
\hline $\begin{array}{l}\text { Immigration/ } \\
\text { Migrants/ Race }\end{array}$ & 7 & 8 & 9 & 4 & 7 \\
\hline Europe & 8 & 5 & 15 & 7 & 10 \\
\hline Business & 9 & 6 & 13 & 14 & 8 \\
\hline Social security & 10 & 10 & 17 & 11 & 10 \\
\hline
\end{tabular}

17 (1) Main issues in election news coverage in TV and press coverage produced on weekdays (i.e. Monday to Friday inclusive). TV = Channel 4 News $(7 \mathrm{pm})$, Channel 5 News $(6.30 \mathrm{pm}), \mathrm{BBC} 1$ News at 10, ITV1 News at 10, BBC2 Newsnight, Sky News 8-8.30pm; Press = The Guardian, Independent, Times, Daily Telegraph, Daily Mail, Daily Express, Mirror, Sun, Star and Metro.

Sources: Loughborough University Communication Research Centre, Media Coverage of the 2015 General Election Campaign, Reports, n¹-5, 13 April 2015, 18 April 2015, 24 April 2015, 1 May 2015, 11 May 2015.

In fact, the political commentators faithfully followed the Conservatives' lead on the subject. In 2010, the Conservatives' general election campaign had failed to fully exploit the idea of New Labour's economic incompetence in both preventing and eliminating the financial and economic crises. As a result, the Conservatives had fallen 20 seats short of an overall majority at the House of Commons and had had to form a coalition with the Liberal-Democrats. In 2015, the mistake of a disappointing campaign was not to be repeated. As of 2012, the Conservatives therefore renewed their contract with one of the best election strategists of the time: Australian Lynton Crosby. Crosby had not managed to lead the Conservatives to power at the 2005 general election. Yet, he remained famous for his past success in Australia, since he had actively contributed to the election of Liberal Prime Minister John Howard four times in a row, from 1996 to 2004. In Britain, he had recently regained his reputation, when helping Boris Johnson to be repeatedly elected as Mayor of London, in 2008 and 2012.

Crosby is known for getting straight to the point. When called for the 2015 campaign preparation, he was reported to have told David Cameron to "scrape the barnacles off the boat" 29 and rather focus on the issues that mattered to the real citizens. Before and during the campaign, the top three concerns of the British were the NHS, immigration, and the economy, as shown in the various Economist/Ipsos MORI polls conducted at the time and summed up in Table 2 below. The macroeconomic state of the United Kingdom was not at the top of the population's concerns, a fact that clearly transpired during the televised debates, when the audience was offered the chance to put questions to the political leaders. ${ }^{30}$ The British ordinary citizen was much more keen to know about every-day-life issues like help to the elderly, the disabled, the sick and children. 
Table 2 - Top 10 most important issues facing Britain today

\begin{tabular}{|l|l|l|l|l|l|}
\hline Ranks & 2014 & January 2015 & February 2015 & March 2015 & April 2015 \\
\hline 1 & $\begin{array}{l}\text { Immigration } \\
(38 \%)\end{array}$ & $\begin{array}{l}\text { NHS } \\
(45 \%)\end{array}$ & $\begin{array}{l}\text { NHS } \\
(41 \%)\end{array}$ & $\begin{array}{l}\text { Immigration } \\
(45 \%)\end{array}$ & $\begin{array}{l}\text { NHS } \\
(47 \%)\end{array}$ \\
\hline 2 & $\begin{array}{l}\text { Economy } \\
(34 \%)\end{array}$ & $\begin{array}{l}\text { Immigration } \\
(34 \%)\end{array}$ & $\begin{array}{l}\text { Immigration } \\
(34 \%)\end{array}$ & $\begin{array}{l}\text { NHS } \\
(38 \%)\end{array}$ & $\begin{array}{l}\text { Immigration } \\
(36 \%)\end{array}$ \\
\hline 3 & $\begin{array}{l}\text { NHS } \\
(27 \%)\end{array}$ & $\begin{array}{l}\text { Economy } \\
(33 \%)\end{array}$ & $\begin{array}{l}\text { Economy } \\
(30 \%)\end{array}$ & $\begin{array}{l}\text { Economy } \\
(28 \%)\end{array}$ & $\begin{array}{l}\text { Economy } \\
(36 \%)\end{array}$ \\
\hline
\end{tabular}

Sources: Economist/Ipsos-MORI, Issues Index 2014 aggregate data, 14 January 2015; Issues Facing Britain (Issues Index), January 2015, February 2015, March 2015, April 2015.

As a matter of fact, Healthcare/NHS/Hospitals remained the first issue the public quoted, in January and March 2015, when asked about what would help them decide which party to vote for. ${ }^{31}$ But the NHS, like immigration, was a field in which the Conservatives' records and proposals were very likely to be criticized..$^{32}$ With the prospect of being attacked by the Labour Party on the NHS, as was indeed the case in the very first campaign poster of the opposition party, ${ }^{33}$ and by UKIP over immigration, it was a better strategy for the Conservatives to shift the attention towards their economic strengths.

\section{The Details of the Conservatives' Economic Litany}

Consequently, in January 2015, the first Conservative campaign poster paved the way for a battle focused on the economy. The poster, which showed an upward road slicing through two flourishing crop fields and leading to a clearing in green forest in the background, proposed to "[...] stay on the road to a stronger economy". Under the inviting positive slogan, the Conservatives listed the following economic achievements: "1.75 million more people in work. 760,000 more businesses. The deficit halved." ${ }^{34}$ These were three of the four recurring achievements put forward throughout the Conservatives' campaign. Cameron added that of "the fastest growing economy of any major Western economy" ${ }^{35}$ during the televised interview led by Jeremy Paxman on 26 March 2015. The message was positive, concise but accurate, easy to remember and to quickly drop during any televised interview, and easily understandable by the public. As it turned out, zero inflation also happened to be mentioned, but was not part of the Conservatives' preferred litany.

After Parliament was dissolved, on 30 March 2015, Cameron went on directing the national debate towards the economy, as he dedicated more than $60 \%$ of his 10 Downing Street statement to economic issues. His statement laid the four pillars of the Conservative Party's campaign: the desperate situation inherited five years before, the government's achievements (with references to the four achievements mentioned above), the Conservatives' programme for the next five years, and the Labour Party's economically destructive plan. The speech enclosed the two main phrases to be attached to the Labour Party. The past record of New Labour was summed up in the expression " Britain [...] on the brink", to qualify the 2010 economic situation; the possible future 
performance of Ed Miliband was anticipated as "economic chaos". ${ }^{36}$ It is worth noticing that in this speech, the NHS was hardly mentioned, with just a reference stating its financing and improvement depended on a growing economy that only the Conservatives could secure. Immigration was ignored altogether.

From then on, the Conservatives' campaign sounded like a variation on the same theme. We will only take two more striking examples, to be compared to the excerpts quoted above. At the live televised debate gathering the seven main party leaders on 2 April 2015, Cameron started his opening statement saying:

Five years ago, this country was on the brink. [...] we've been working with the British people through a long-term economic plan. And that plan is working. There're almost two million more people in work. It's a balanced plan so we've invested in our NHS as well as reducing the deficit [...]. And the plan's working because last year, we had the fastest growing economy of any of the major Western countries $[. ..] .^{37}$

And he closed his statement in this way:

[...] I've tried to have one task in mind above all others and that has been turning our economy around, putting the country back to work [...]. We've created two million jobs. Let's create a job for everyone who wants and needs one. We've cut the deficit in half. Let's clear it altogether [...]..$^{38}$

Thirteen days later on BBC One, when asked about what grade he would give his government's records, Cameron answered:

What I've tried to do [...] is [...] to turn the economy around, and two million more people in work, 750000 more businesses operating in Britain, growing faster than the other major Western countries, I think that's a strong record [...]. We got two million more people in work, now let's get full employment. We cut the deficit in half as a share of GDP, let's now get rid of it altogether. [...] stick to the plan and build on it. ${ }^{39}$

As can be seen, Cameron's economic message that was delivered to the general public via popular media was very repetitive. Some political commentators went so far as to remark that its litany nature even led to a loss of effectiveness..$^{40}$ To be fair, the out-going Prime Minister sometimes complemented the campaign's simplified message with some details about his government's economic achievements. For example, when questioned about the job creation benefiting foreign nationals, Cameron argued that the proportion had slumped from $90 \%$ in 2010 to two-thirds in 2015. He even added that $80 \%$ of the jobs created were full-time jobs. ${ }^{41}$ But on the whole, Cameron stuck to the slogans. Details and explanations were left to Conservative junior political figures, who had more time to express themselves during debates about specific questions. For example, when Exchequer Secretary to the Treasury Priti Patel was invited to debate against Shabana Mahmood, the shadow Exchequer Secretary, about employment, she specified that threefifths of the jobs that had been created over the last five years were highly skilled jobs and only $2 \%$ were zero-hour contracts..$^{42}$ Yet, it is not unreasonable to believe that Priti Patel, like any other Conservative junior political figure, had probably less chance to reach the general public than Cameron or Osborne expressing themselves on the main television channels.

Moreover, if the recurring simple economic message was sometimes complemented with details about the nature of the government's economic achievements, it was seldom accompanied by explanations about the methods and means that had been implemented. When explanations were given, they concerned only the achievements of deficit 
reduction and job creation. First, about the deficit reduction, Cameron repeatedly referred to the "difficult decisions" his government had taken. Yet, he cautiously avoided going into any detail. For example, he proudly declared that the government had "saved 20 billion in welfare over the last Parliament", ${ }^{43}$ but did not take the risk of marking out some unpopular saving measures. Second, to explain job creation, Cameron enumerated the improvements made to the education system, the training of apprentices, and the reform of the welfare system. ${ }^{44} \mathrm{He}$ was also heard saying: "It is only with a strong economy that we can achieve the things that we dream of: jobs, and homes, and livelihoods for more people." 45 This meant that good macroeconomic conditions were indeed the key to success. Yet Cameron did not elaborate on these conditions. Moreover, he never precisely explained how his government had realized the two achievements of economic growth and low inflation. His only hint of an explanation was the recurring reference to the "long-term economic plan". But the details of this three-part plan were not explicitly recalled. When some were alluded to, they did not concern the monetary activism part of the plan. Rather, they were related to the credible fiscal policy part, as seen above, and also to the supply side reform part with, for example, the mention of the Help-to-Buy scheme that had made house purchase more affordable. ${ }^{46}$

\section{Monetary Policy Issues in George Osborne's Messages}

The fact that the Prime Minister never made any reference to the monetary activism implemented by his outgoing government might lead to the hypothesis that the subject of monetary policy was the prerogative of the Chancellor of the Exchequer. But Osborne was not the Conservatives' leading campaign figure. As the designer and presenter of fiscal austerity measures, he was not very popular. In March 2015, only $43 \%$ of poll respondents said they were satisfied with the way Osborne had done his job. ${ }^{47}$ In light of this lack of popularity, it was better for the Conservatives to let Cameron occupy centre stage.

Table 3 - Ranking of the main political figures' media appearances ${ }^{(1)}$

\begin{tabular}{|l|l|l|l|l|l|}
\hline & $\begin{array}{l}30 \text { March- 7 } \\
\text { May }\end{array}$ & $\begin{array}{l}30 \text { March- 8 } \\
\text { April }\end{array}$ & $\begin{array}{l}9 \text { April- 15 April- 22 } \\
\text { April }\end{array}$ & $\begin{array}{l}\text { 23 April- 29 } \\
\text { April }\end{array}$ \\
\hline $\begin{array}{l}\text { David } \\
\text { Cameron }\end{array}$ & 1 & 1 & 1 & 2 & 1 \\
\hline Ed Miliband & 2 & 2 & 2 & 1 & 2 \\
\hline Nick Clegg & 3 & 3 & 3 & 5 & 5 \\
\hline $\begin{array}{l}\text { Nicola } \\
\text { Sturgeon }\end{array}$ & 4 & 6 & 7 & 3 & 3 \\
\hline Nigel Farage & 5 & 4 & 5 & 4 & 4 \\
\hline $\begin{array}{l}\text { George } \\
\text { Osborne }\end{array}$ & 6 & 5 & 4 & 15 & 6 \\
\hline
\end{tabular}




\begin{tabular}{|l|l|l|l|l|l|}
\hline $\begin{array}{l}\text { Natalie } \\
\text { Bennett }\end{array}$ & 12 & 20 & 9 & 10 & 11 \\
\hline Leanne Wood & 17 & 10 & $-(3)$ & 10 & - \\
\hline
\end{tabular}

(1) Ranks according to the percentage of appearances of a political figure as a proportion of the total number of media coverage items analysed. Items produced in TV and press coverage on weekdays (see note (1), Table 1, supra).

(2) Position shared with Boris Johnson.

(3) Dropped out of the top 20.

Sources: Loughborough University Communication Research Centre, Media Coverage of the 2015 General Election Campaign, op. cit.

As can be seen in Table 3 above, Osborne was indeed not in the top five of the main political figures appearing in the media, even if he did far better than the leaders of two of the main political parties in the United Kingdom, Natalie Bennett (the Green Party), and Leanne Wood (Welsh Plaid Cymru). When he physically appeared in the media while campaigning, he was usually staged so as to look like the "nice guy" close to British industry and workers. This is what could be seen, for example, in the BBC electronic site daily section called "Election 2015 In Pictures", which exhibited 242 pictures of the campaign taken from 30 March to 6 May 2015. Of the nine pictures in which Osborne was present, three showed him paying an interested visit to a British company and two even participating in the activity, making pizzas at Pizza Express and changing oil on a car at Hawkins Motor Group garage. In the other four pictures, he just stood with another public figure. ${ }^{48}$ The Conservatives' staging of Osborne as "working Britain's friend" appears even more obvious in The Telegraph's electronic 64 picture book of the Conservatives' campaign. In the selection of 13 pictures representing Osborne, 11 were snapshots of the Chancellor actively visiting a company or a working site. ${ }^{49}$

3 This article is not the place to review all the pictures taken of the Chancellor campaigning for the 2015 general election. There were many others. Yet, it is worth noting that no picture could be found that purposefully evoked the outgoing government's success in monetary activism. The author's search for pictures of Osborne in front of the Bank of England or with Mark Carney, for example, remained fruitless. As a matter of fact, pictures of the pair are not numerous on the Internet. Google displays only fewer than a dozen of different ones, some of them taken at the same event, either from May 2013 to August 2014, or from May 2015.

A Search for reported statements did not bring better findings. Nowhere was Osborne reported to have acknowledged publicly the positive role of monetary policy in achieving the economic growth that the Conservatives were promoting during the general election campaign. Yet, two annual events could have given Osborne this opportunity during the campaign: the Budget and the remit to the Governor of the Bank of England, which were presented and sent on 18 March 2015. It was, in fact, hardly the case, as we will see now.

The Chancellor opened his Budget speech with the idea that Britain was growing and, faithful to the campaign strategy, recounted the government's various economic achievements seen above, just adding that of the replacement of bank bail-outs and nationalizations by the profitable sale of bank shares back to the private sector. He then 
linked the achievements to the British long-term economic plan, but did not go back to the three components of the plan. When speaking about employment, he actually said the plan was "based on the premise that if you provide[d] economic stability [...] then you w[ould] create jobs too". He thus reckoned economic stability was the main root of the government's economic success, but he did not mention how this stability was achieved. And when he more specifically covered monetary policy, Osborne just factually explained the inflation level and announced the future policy as regards gilts and long-term interest rates. ${ }^{50}$ The part of the speech dedicated to monetary policy therefore remained very neutral.

41 The letter to the Governor of the Bank of England, that Osborne wrote to introduce the remit, was not more promotional, as it remained focused on regulatory aspects. Indeed, the objective of the letter and the remit is to establish technically the monetary framework. The documents do not contain any evaluation of the economic situation of the country or of the results of monetary policy. In March 2015, they therefore consisted in reaffirming the framework, assessing the progress of the reform and announcing the next steps of the latter. ${ }^{51}$ If, in the rosy circumstances of good GDP growth for 2014, Osborne took the opportunity to acknowledge the effectiveness of the monetary policy and pay tribute to Carney and the Bank of England's work, it remained off the media record.

Last, the author found no evidence in media reporting of the campaign of Osborne explaining economic growth by the effectiveness of his government's 2013 monetary policy reform. Similarly, no evidence was found of Osborne explaining economic growth by anything more than the "long-term economic plan" litany. Nevertheless, the Chancellor was heard to say that the years of economic growth should be used by the government to reduce its deficit so as to create the economic stability necessary for business investment and job creation..$^{52}$ That was similar to Cameron's reference to a strong economy being the necessary condition to any broader political achievement. But how this strong economy had indeed materialised was never precisely recalled.

\section{The Conservatives' Reasons for De-Politicizing the Monetary Policy}

The fact that the Conservatives did not allude to their monetary policy reform, while hammering home their economic achievements tirelessly, in their popular campaign that targeted ordinary citizens, contrasts quite clearly with the stance of re-politicizing the monetary policy which surrounded the reforms implemented in 2013. In fact, the Conservatives' attitude amounted to de-politicizing monetary policy to its extreme limits. Indeed, not only did the outgoing government relinquish any link to, and thus any accountability for, monetary policy and its possible results, but they removed the issue from the political debate. There might be several reasons for this strategy.

The first reason is purely economic and stems from the fact that the actual influence of the outgoing government's monetary policy actions on the United Kingdom's growth is difficult to measure. There is an economists' consensus about the fact that the 2010 recession, as measured by GDP negative growth, would have been even worse without the first wave of quantitative easing (QE1), implemented by New Labour. ${ }^{53}$ But the impact on growth of the Conservatives' further QE2 and QE3 has remained uncertain. The same is 
true for the effects that the FLS and Help-to-Buy scheme may have had on the level of lending while, at the same time, the schemes have been suspected of contributing to demand-led housing price inflation. ${ }^{54}$ The only actual economic success seems to have come from forward guidance. In November 2014, Carney remarked that the markets' expectations that the Bank of England's interest rate would rise "to a more limited extent and at a more gradual pace" ${ }^{55}$ had led to a decrease in the rates offered to households and businesses. This could only have had positive effects on growth. But if forward guidance had met with economic success, it was not well understood by the general public.

Forward guidance really started on 7 August 2013 when the MPC announced that interest rates would not be raised as long as the unemployment rate did not fall to $7 \%$. This policy was meaningful as it rested on data everyone understood. But then, in February 2014, as the unemployment rate approached the threshold, the MPC changed its message. It established Forward Guidance II, which linked the base rate future rises to the level of absorption of the economy's spare capacity. The absence of immediate interest rate rises was rather good news. But the side effect was that monetary policy lost credibility in the eyes of the ordinary citizen because first, the MPC seemed to have suddenly changed its mind and, second, it had replaced its message by something far more obscure. It meant that, even if in purely economic terms, Osborne's 2013 monetary reform seemed to have delivered, this achievement was inoperable as a campaign argument, because of people's misunderstanding of the ways forward guidance had been rolled out by the MPC.

By contrast, low inflation and low interest rates were two economic facts, related to monetary policy, that were grasped by all. But inflation was far too low as regards the target of 2\% confirmed year after year in the Treasury's remit to the Bank of England. Since the Bank of England Act of 1998 requires the Governor to write to the Chancellor when the actual inflation rate departs from the target by more than one percentage point, Carney had written an open letter to Osborne on 12 February 2015. He had placed most of the responsibility for undershooting the target on oil and energy price decreases, and put much emphasis on the temporary aspect of this deviation from the target. ${ }^{56}$ Osborne had accepted the explanations straight away. Yet, there was a risk that not only the MPC's operational effectiveness, but also the Treasury's designing competence, might be called into question. Indeed, the government had paradoxically welcomed the transgression of their own directives in December 2014, as we have seen, ${ }^{57}$ and this had encouraged unsettling speculations about whether it was not time to change the nature of the target altogether ${ }^{58}$ It was therefore preferable for the outgoing Treasury team not to insist too much on the subject of low inflation, that they were not fully responsible for, anyway.

47 As for low interest rates, they were the results of the MPC's autonomous operations. The outgoing government could not claim credit for them. More than that they should not do so, because it would compromise the central bank's independence. In the summer of 2014, Conservative Member of Parliament Mark Field had already accused Carney of having a " clear bargain" with Osborne not to raise interest rates before the election. Labour Treasury Committee member John Mann had followed suit, declaring that it was "abundantly clear that Mark Carney [was] attempting to delay interest rate increases until after the election when they [would] rise immediately" ${ }^{59}$ which, in the end, has not proved true. Another Labour member of the Treasury Committee, Teresa Pearce, had also suggested that the Bank of England was not "free of political interference" ${ }^{60}$ Not only were such accusations likely to undermine the whole British monetary policy framework, but in election times, they 
might also question the outgoing government's integrity. Carney had quickly managed to silence gossip, but during the general election campaign, the Conservatives could not take the risk of soliciting criticism by showing any complicity with the Governor. As regards interest rates, the best stance to adopt would have been to congratulate the MPC for its effectiveness. But that would have implied blurring the message that the government's long-term economic plan was working, since the credit of economic growth would thus have been shared with a third party. The Conservatives already had to make the electorate forget that, over the last five years, they had led a Coalition government. Indeed, while the Conservatives claimed they had not been able to achieve all that they wanted to because of the Coalition, ${ }^{6}{ }^{6}$ the Liberal Democrats were more than ready to try to step into the limelight. For example, as regards economic growth, Liberal Democrat Treasury Minister Danny Alexander was reported as saying that his party had been the " rock of stability on which [the] recovery had taken root." ${ }^{62}$

\section{Conclusion}

The contrast between the United Kingdom's economic turmoil, in which the Conservative-Lib-Dem government was formed in 2010, and the comparative prosperity recorded in 2015 represented the main general election asset of the Conservatives. It was therefore chosen as the primary issue of the party's campaign - even though the public was more concerned with the themes of the NHS and immigration. The strategy seems to have worked since, against all predictions and polls, the Conservatives won a majority of seats in the House of Commons and formed the first Conservative government since 1997.

Regarding the economy, the strategy that the Conservatives deployed to defend their economic competence was the litany-like use of a limited number of repetitive short soundbites, which symbolised the principal economic achievements of the government. With the predominance of this litany, there was hardly any room for explanations about the ways and means used to reach these achievements, and absolutely no mention of the government's monetary policy actions.

The truth is that the exact impact of this policy is not easily measurable, except for the reform consisting in the introduction of forward guidance. Yet while forward guidance appears to have been effective economically, its dynamic implementation, evolving with conditions, undermined its credibility in the eyes of the public, and so prevented its use as a campaign argument. What was clear to the public was historically low inflation and interest rates, which were both the results of the independent operations of the Bank of England. It seemed more dangerous than anything else to try and claim credit for the former, as zero inflation was too much of a deviation from the symmetric inflation target. As for the latter, it had already been exploited by MPs to accuse Mark Carney of electoral collusion with George Osborne.

Eventually, the way the Conservatives dealt - or did not deal - with monetary policy during the general election campaign corresponds to a move to renewed depoliticization, which contrasted with that of re-politicization observed in 2013. In the end, the Conservatives denying themselves the use of monetary policy for electoral purposes tends to prove the robustness of the monetary policy framework, based on the operational independence of the Bank of England. The shift in focus from monetary policy to fiscal and supply side measures also suggests the latter might have regained potency in the generation of growth. 


\section{BIBLIOGRAPHY}

ALLEN, Katie. "UK workers set for first real pay rise for four years", The Guardian, 14 April 2014.

$B B C$. "Lynton Crosby goes full time for Tories in £0.5m deal”, 3 November 2013.

BBC. "Election 2015 In Pictures", <http://www.bbc.co.uk/search?q=election+2015+in +pictures\&sa_f=search-product\#page=3 ’, accessed 25 July 2015.

BBC Two. "David Cameron calls 2015 General Election (30Mar15)", Speech announcing the dissolution of Parliament, Daily Politics, 30 March 2015, ' https://www.youtube.com/watch? v=pvxS0ygbghs ${ }^{>}$, accessed 25 July 2015.

BENNETT, Asa. “Bank Of England 'Blind' To Political Pressure Not To Raise Interest Rates, Says Mark Carney", The Huffington Post, 12 November 2014.

BURLEY, Kay (moderator). "Cameron \& Miliband - the battle for number 10", Sky News 4, 26 March 2015

BURNHAM, Peter. "Depoliticising Monetary Policy: The Minimum Lending Rate Experiment in Britain in the 1970s", New Political Economy, London: Routledge, vol. 16, Issue 4, September 2011, pp. 463-480.

CARNEY, Mark. "Letter from the Governor to the Chancellor”, Bank of England, 12 February 2015.

CARNEY, Mark. “Opening remarks", at the Inflation Report Press Conference, 12 November 2014, ‘http://www.bankofengland.co.uk/publications/Documents/inflationreport/2014/ irspnote141112.pdf , accessed 25 July 2015.

Channel 4. "Labour scornful of Osborne's good news 'topping”, 31 March 2015, ‘http:// www.channel4.com/news/george-osborne-uk-growth-economy-election-2015’, accessed 25 July 2015.

COBHAM, David. "Monetary policy under the Coalition", posted on 16 April 2015, 'http:// www.coalitioneconomics.org/uncategorized/monetary-policy-under-the-coalition/”, accessed 25 July 2015.

DAVIS, Evan (interviewer). “The Leader interviews: David Cameron (Conservatives)”, BBC One, 15 April 2015.

DIMBLEBY, David (moderator). “Question Time: Election Leaders Special | UK Election 2015”, BBC One, 30 April 2015.

ECONOMIC INTELLIGENT UNIT (The), "The Conservative Party is losing the election campaign", 20 April 2015, ‘http://country.eiu.com/article.aspx?articleid=1753090359\&Country=United\% 20Kingdom\&topic=Politics ${ }^{>}$, accessed 25 July 2015.

ECONOMIST (The), “Wrong target?”, 12 February 2015.

ETCHINGHAM, Julie (moderator). “The ITV Leaders Debate”, ITV, 2 April 2015.

EUROSTAT. ‘http://appsso.eurostat.ec.europa.eu/nui/show.do?dataset=une_rt_a\&lang=en’, accessed 25 July 2015. 
FLINDERS, Matthew. "Memorandum", Written Evidence, Select Committee on Public Administration, November 2005, ' http://www.publications.Parliament.uk/pa/cm200607/ cmselect/cmpubadm/122/122we12.htm>, accessed 25 July 2015.

INDEPENDENT (The), "Bank of England's Mark Carney accused of delaying rate hike ahead of General Election”, 18 August 2014.

IPSOS MORI. “The Budget and the Economy Infographic”, Pre-Budget 2015 poll, 18 March 2015.

ITN - Channel 4. “Debate - Employment: are people better off in 2015?”, 1 April 2015.

ITV. "Cameron: We don't face European countries' deflation problem", ITV News, 13 Jan 2015, 5:24 pm, ‘http://www.itv.com/news/story/2015-01-14/osborne-lets-celebrate-effects-of-lowinflation-not-fear-them/ $>$, accessed 25 July 2015.

ITV. “Osborne buoyed by stronger economic figures”, ITV News, 31 March 2015, 9:36 am, " http:// www.itv.com/news/update/2015-03-31/uk-economy-grew-by-0-6-in-the-fourth-quarter/”, accessed 25 July 2015.

ITV. "Osborne: Celebrate effects of low inflation not fear them", ITV News, 13 Jan 2015, 11:33 pm, <http://www.itv.com/news/story/2015-01-14/osborne-lets-celebrate-effects-of-low-inflationnot-fear-them/ ${ }^{>}$, accessed 25 July 2015.

MARR, Andrew (interviewer). “The Andrew Marr Show”, BBC One, 20 April 2015.

NEWMAN, Cathy (interviewer). “Osborne: 'Competence versus chaos' - video”, Channel 4, 02 January 2015, ‘http://www.channel4.com/news/osborne-chancellor-george-conservativeposter-taxation>, accessed 25 July 2015.

OFFICE FOR NATIONAL STATISTICS. House Price Index, March 2015, Table 22: Housing market, ‘http://www.ons.gov.uk/ons/publications/re-reference-tables.html?edition=tcm\% 3A77-364254 , accessed 25 July 2015

OFFICE FOR NATIONAL STATISTICS. "Public Sector Finances, March 2015", Statistical Bulletin, 23 April 2015, p. 13.

OFFICE FOR NATIONAL STATISTICS. "Understanding Average earnings for the Continuously Employed - Using the Annual Survey of Hours and Earnings 2014", 18 May 2015.

OFFICE FOR NATIONAL STATISTICS. “A01: Summary of labour market statistics”, 15 July 2015, ‘http://www.ons.gov.uk/ons/taxonomy/index.html?nscl=Unemployment+Rates\#tab-datatables', accessed 25 July 2015.

OSBORNE, George. “Budget 2013: Chancellor's statement”, Oral statement to Parliament, HM Treasury, 20 March 2013.

OSBORNE, George. "Remit for the Monetary Policy Committee”, HM Treasury, 20 March 2013.

OSBORNE, George. “Chancellor George Osborne's Budget 2015 speech”, HM Treasury, 18 March 2015.

OSBORNE, George. “The Chancellor's letter to the Governor of the Bank of England setting the remit for the Monetary Policy Committee”, HM Treasury, 18 March 2015.

PAXMAN, Jeremy (interviewer). “Cameron \& Miliband - the battle for number 10”, Sky News 4, 26 March 2015, ‘https://www.youtube.com/watch?v=LAoMFz7qaR0’, accessed 25 July 2015.

SCOTSMAN (The), "UK food prices rising at slowest rate in decade", Monday 29 June 2015. 
SPENCE, Peter. "Don't be fooled: interest rates have been changing since the crisis", The Telegraph , 1 March 2015, ‘http://www.telegraph.co.uk/finance/bank-of-england/11443530/Dont-befooled-interest-rates-have-been-changing-since-the-crisis.html ${ }^{>}$, accessed 25 July 2015.

TAYLOR, Ciaren et al. “An Examination of Falling Real Wages”, office for National Statistics, 31 January 2014.

TELEGRAPH (The), “General Election 2015: David Cameron and Conservatives on the campaign trail”, ‘http://www.telegraph.co.uk/news/general-election-2015/11494250/GeneralElection-2015-David-Cameron-and-Conservatives-on-the-campaign-trail.html? frame=endScreen', accessed 25 July 2015.

\section{NOTES}

1. See David CAMERON in Jeremy PAXMAN (interviewer), "Cameron \& Miliband - the battle for number 10", Sky News 4, 26 March 2015, ‘https://www.youtube.com/watch?v=LAoMFz7qaR0”, accessed 25 July 2015.

2. See George OSBORNE in Cathy NEWMAN (interviewer), “Osborne: 'Competence versus chaos' video”, Channel 4, 02 January 2015, ‘http://www.channel4.com/news/osborne-chancellorgeorge-conservative-poster-taxation’, accessed 25 July 2015.

3. George OSBORNE, "Budget 2013: Chancellor's statement", Oral statement to Parliament, HM Treasury, 20 March 2013.

4. In a letter addressed to the Treasury and Civil Service Committee Chairman at the beginning of October 1992, Norman Lamont set "for the remainder of this Parliament [...] the objective of keeping underlying inflation within a range of 1-4 per cent". Letter available at "http:// webarchive.nationalarchives.gov.uk/20130129110402/http://www.hm-treasury.gov.uk/d/

foi_dis_7_john_watts_081092.pdf ${ }^{>}$, accessed 25 July 2015.

5. The Treasury has kept targeting inflation directly since 1992. Instead of a target range, a symmetric inflation target has been adopted since 1998, from which the actual rate might depart in exceptional circumstances. The first target, fixed in 1998, was for inflation, as measured by growth in the Retail Price Index excluding mortgage interest payments (RPIX), to be stabilized at around 2.5\% in the medium term. Since December 2003, inflation has been measured in terms of the Consumer Price Index (CPI) growth and should be kept close to $2 \%$.

6. Forward guidance is a form of communication dedicated to the management of expectations of future monetary policy. It consists in clarifying the authorities' reaction function so that market participants may know more acutely what to expect.

7. George OSBORNE, "Remit for the Monetary Policy Committee”, HM Treasury, 20 March 2013.

8. George OSBORNE, "Budget 2013: Chancellor's statement", op. cit.

9. Matthew FLINDERS, "Memorandum", Written Evidence, Select Committee on Public Administration, November 2005, ‘http://www.publications.Parliament.uk/pa/cm200607/ cmselect/cmpubadm/122/122we12.htm ’, accessed 25 July 2015.

10. See Peter BURNHAM, "Depoliticising Monetary Policy: The Minimum Lending Rate Experiment in Britain in the 1970s", New Political Economy, London: Routledge, vol. 16, Issue 4, September 2011, pp. 463-480.

11. George OSBORNE, “Budget 2013: Chancellor's statement”, op. cit.

12. Ibid.

13. Ibid.

14. Ibid.

15. Ibid. 
16. See Nicholas SOWELS, "Fiscal Policy and Public spending Under the Coalition Government, 2010-2015" in this issue.

17. See OFFICE FOR NATIONAL STATISTICS, "Public Sector Finances, March 2015", Statistical Bulletin, 23 April 2015, p. 13.

18. Tweet reproduced on the site of ITV, in "Osborne buoyed by stronger economic figures", 31 March 2015, 9:36 am, ¿http://www.itv.com/news/update/2015-03-31/uk-economy-grew-by-0-6in-the-fourth-quarter/>, accessed 25 July 2015.

19. Quoted on ITV, "Cameron: We don't face European countries' deflation problem", 13 Jan 2015, 5:24 pm, ‘http://www.itv.com/news/story/2015-01-14/osborne-lets-celebrate-effects-of-lowinflation-not-fear-them/ $>$, accessed 25 July 2015.

20. Quoted on ITV, "Osborne: Celebrate effects of low inflation not fear them", 13 Jan 2015, 11:33 pm, ‘http://www.itv.com/news/story/2015-01-14/osborne-lets-celebrate-effects-of-lowinflation-not-fear-them/>, accessed 25 July 2015.

21. This slight decrease has been the second one since the crisis. The commercial banks' average interest rate had dramatically slumped from 5\% in the winter of 2008 to $3 \%$ in the spring of 2009 . It had then stabilized slightly below 3\% until September 2012. See Peter SPENCE, "Don't be fooled: interest rates have been changing since the crisis", The Telegraph, 1 March 2015, “http:// www.telegraph.co.uk/finance/bank-of-england/11443530/Dont-be-fooled-interest-rates-havebeen-changing-since-the-crisis.html' , accessed 25 July 2015.

22. EUROSTAT, ‘http://appsso.eurostat.ec.europa.eu/nui/show.do?dataset=une_rt_a\&lang=en’, accessed 25 July 2015.

23. Unemployment rates measured over the three preceding months until the end of the month that is quoted. OFFICE FOR NATIONAL STATISTICS, "A01: Summary of labour market statistics", 15 July 2015, ‘http://www.ons.gov.uk/ons/taxonomy/index.html?nscl=Unemployment +Rates\#tab-data-tables , accessed 25 July 2015.

24. OFFICE FOR NATIONAL STATISTICS, "Understanding Average earnings for the Continuously Employed - Using the Annual Survey of Hours and Earnings 2014", 18 May 2015.

25. Ciaren TAYLOR et al., "An Examination of Falling Real Wages", office for National Statistics, 31 January 2014.

26. Katie ALLEN, "UK workers set for first real pay rise for four years", The Guardian, 14 April 2014.

27. OFFICE FOR NATIONAL STATISTICS, House Price Index, March 2015, Table 22 Housing market, ‘http://www.ons.gov.uk/ons/publications/re-reference-tables.html?edition=tcm\% 3A77-364254', accessed 25 July 2015

28. See THE SCOTSMAN, “UK food prices rising at slowest rate in decade", Monday 29 June 2015. 29. Reported by BBC, "Lynton Crosby goes full time for Tories in $£ 0.5 \mathrm{~m}$ deal", 3 November 2013. 30. See Kay BURLEY (moderator), "Cameron \& Miliband - the battle for number 10", sky News 4, 26 March 2015; and David DIMBLEBY (moderator), "Question Time: Election Leaders Special | UK Election 2015", BBC One, 30 April 2015.

31. See IPSOS MORI, “The Budget and the Economy Infographic", Pre-Budget 2015 poll, 18 March 2015.

32. See James HAMPSHIRE, "The Cost of Broken Promises: Immigration in the General Election, Immigration and the 2015 UK General Election", and Louise DALINGWATER, "The NHS at the heart of the election campaign", both in this issue.

33. The Labour Party's first campaign poster showed a picture of Cameron and said: "The Tories want to cut spending on public services back to the levels of the 1930s, when there was no NHS / The NHS as you know it cannot survive five more years of David Cameron".

34. The poster was criticized for its false claims, the deficit being halved only in GDP proportion, and the German origin of the picture.

35. David CAMERON in Jeremy PAXMAN (interviewer), op. cit. 
36. David CAMERON, "David Cameron calls 2015 General Election (30Mar15)", Speech announcing the dissolution of Parliament, BBC Two, Daily Politics, 30 March 2015, ‘https:// www.youtube.com/watch?v=pvxS0ygbghs?, accessed 25 July 2015.

37. David CAMERON in Julie ETCHINGHAM (moderator), “The ITV Leaders Debate", ITV, 2 April 2015.

38. Ibid.

39. David CAMERON in Evan DAVIS (interviewer), "The Leader interviews: David Cameron (Conservatives)", BBC One, 15 April 2015.

40. See THE ECONOMIST INTELLIGENCE UNIT, "The Conservative Party is losing the election campaign", $20 \quad$ April 2015, ‘http://country.eiu.com/article.aspx? articleid=1753090359\&Country=United\%20Kingdom\&topic=Politics〉, accessed 25 July 2015.

41. David CAMERON in Andrew MARR (interviewer), "The Andrew Marr Show”, BBC One, 20 April 2015.

42. See Priti PATEL in "Debate - Employment: are people better off in 2015?", ITN - Channel 4, 1 April 2015.

43. David CAMERON in Jeremy PAXMAN (interviewer), op. cit.

44. David CAMERON in Andrew MARR (interviewer), "The Andrew Marr Show", op. cit.

45. David CAMERON in Evan DAVIS (interviewer), op. cit.

46. David CAMERON in Julie ETCHINGHAM (moderator), op. cit.

47. See IPSOS MORI, "The Budget and the Economy Infographic", op. cit.

48. The companies were Lewes Brewery, WWDistribution, and George Bence \& Sons. The public figures were Cameron, Cameron's wife when she and Osborne were listening to Cameron's speech, a conservative party candidate, and the education secretary. See BBC, "Election 2015 In Pictures", 〈http://www.bbc.co.uk/search?q=election+2015+in+pictures\&sa_f=searchproduct\#page=3>, accessed 25 July 2015.

49. The companies were Hawkins Motor, Numatic, Britvic Soft Drinks, Marston Brewery, Pizza Express, and Hecks Cider Farm. The working sites were those of London Victoria subway station, and the interior of a building in construction. Osborne also appeared assisting Cameron in testdriving London's new tube train. Note that out of the 13 pictures, four showed him with Cameron, and two with Boris Johnson. See THE TELEGRAPH, "General Election 2015: David Cameron and Conservatives on the campaign trail", ‘http://www.telegraph.co.uk/news/generalelection-2015/11494250/General-Election-2015-David-Cameron-and-Conservatives-on-thecampaign-trail.html?frame=endScreen ', accessed 25 July 2015.

50. George OSBORNE, "Chancellor George Osborne's Budget 2015 speech", HM Treasury, 18 March 2015.

51. George OSBORNE, “The Chancellor's letter to the Governor of the Bank of England setting the remit for the Monetary Policy Committee”, HM Treasury, 18 March 2015.

52. See George OSBORNE in Cathy NEWMAN (interviewer), op. cit.

53. See David COBHAM, "Monetary policy under the Coalition", posted on 16 April 2015, ‘http:// www.coalitioneconomics.org/uncategorized/monetary-policy-under-the-coalition/”, accessed 25 July 2015.

54. Ibid.

55. See Mark CARNEY, "Opening remarks", at the Inflation Report Press Conference, 12 November 2014, 〈http://www.bankofengland.co.uk/publications/Documents/ inflationreport/2014/irspnote141112.pdf , accessed 25 July 2015.

56. See Mark CARNEY, "Letter from the Governor to the Chancellor", Bank of England, 12 February 2015.

57. See the paragraph about "The Economic Context of the 2015 General Election", supra.

58. See THE ECONOMIST, “Wrong target?”, 12 February 2015. 
59. See THE INDEPENDENT, "Bank of England's Mark Carney accused of delaying rate hike ahead of General Election", 18 August 2014.

60. See Asa BENNETT, "Bank Of England 'Blind' To Political Pressure Not To Raise Interest Rates, Says Mark Carney", The Huffington Post, 12 November 2014.

61. See David CAMERON in Evan DAVIS (interviewer), op. cit.

62. See Danny ALEXANDER in "Labour scornful of Osborne's good news 'topping”, Channel 4, 31 March 2015, 〈http://www.channel4.com/news/george-osborne-uk-growth-economyelection-2015 , accessed 25 July 2015.

\section{ABSTRACTS}

The relative prosperity of Britain in 2015 represented the main asset around which the Conservatives built their general election campaign. The strategy that they deployed was the repetition of a litany of their principal economic achievements, in which no mention was made to the government's monetary policy actions. The fact that the outgoing government did not use the possible success of the last five years' monetary policy as a campaign argument contrasted with the re-politicization of monetary policy that had accompanied the introduction of forward guidance in Britain in 2013. It can be explained by the difficulty of assessing the exact effect of monetary policy on the recovery, the loss of credibility encountered by forward guidance as it was modified according to economic conditions, and the robustness of the framework itself, which is based on the Bank of England's independence.

La prospérité relative de la Grande-Bretagne en 2015 a représenté l'atout majeur autour duquel les Conservateurs ont bâti leur campagne électorale. La stratégie qu'ils ont déployée a consisté à répéter une litanie de leurs principales réussites économiques, dans laquelle ils ont passé leur politique monétaire sous silence. Le fait que le gouvernement sortant n'a pas utilisé les succès probables de la politique monétaire de ces cinq dernières années comme argument de campagne contraste avec la re-politisation de la politique monétaire qui a accompagné l'introduction d'indications sur la trajectoire future des taux d'intérêt directeurs (forward guidance) au Royaume-Uni en 2013. Il peut être expliquée par la difficulté à évaluer l'effet exact de la politique monétaire sur la reprise économique, la perte de crédibilité encourue par la stratégie de communication de la Banque d'Angleterre et la robustesse du cadre de politique monétaire luimême.

\section{INDEX}

Keywords: Conservatives, economy, monetary policy, Bank of England

Mots-clés: Conservateurs, économie, politique monétaire, Banque d'Angleterre

\section{AUTHOR}

\section{NATHALIE CHAMPROUX}

Université Paris Est Créteil 